\title{
ANALISIS KESALAHAN PENGGUNAAN KATA BANTU STRUKTURAL “的, 得, 地” PADA MAHASISWA ANGKATAN 2017
}

\section{7 年的学生使用结构助词 “的、得、地” 的偏误分析}

\author{
Shielyn Angela \\ Alpin Gadman Markali, S.S., M.A., \& Kuo Chun-I, M.A. \\ Program Studi Sastra Tionghoa Universitas Kristen Petra, \\ Siwalankerto 121-131, Surabaya 60236 \\ E-mail: shielynn96@gmail.com
}

\begin{abstract}
ABSTRAK
Penelitian ini bertujuan untuk mengetahui kesalahan, faktor penyebab kesalahan dan cara pandang mahasiswa Universitas Kristen Petra angkatan 2017 prodi Sastra Tionghoa terhadap cara pengajaran kata bantu struktural de(的), de(得) dan de(地). Pendekatan yang digunakan dalam penelitian ini adalah pendekatan deskriptif kualitatif. Teknik pengumpulan data dilakukan dengan melakukan tes dan wawancara. Hasil penelitian menunjukkan bahwa kesalahan terbanyak yang dilakukan mahasiswa adalah kesalahan penggunaan kata bantu struktural de(得) dan de(地). Faktor penyebab mahasiswa melakukan kesalahan adalah: penggunaan kata bantu struktural yang rumit, faktor dalam diri mahasiswa, kurangnya latihan soal dan adanya pengaruh dari bahasa ibu. Selain itu dari hasil penelitian juga dapat diketahui cara pandang mahasiswa terhadap pengajaran kata bantu struktural de(的), de(得) dan de(地) yaitu: cara penjelasan pengajar yang sangat berpengaruh terhadap tingkat pemahaman mahasiswa serta memperbanyak latihan soal dapat membuat mahasiswa tidak mudah melupakan materi yang baru diajarkan. Kesimpulannya adalah penggunaan kata bantu struktural de(得) dan de(地) adalah yang paling sulit, yang membuat mahasiswa banyak melakukan kesalahan dan di antara ketiga kata bantu struktural, kesalahan penambahan dan penghilangan kata bantu stuktural de(的) yang paling banyak dilakukan mahasiswa.
\end{abstract}

Kata Kunci: Analisis Kesalahan, Kata Bantu Struktural, “的, 得 dan 地” 


\section{摘要}

本研究的目的是描述彼得拉大学中文系 2017 年的学生使用结构助词 “的”、“地”、得”的偏误、产生偏误的原因和学生对结构助词教学的看法。 本研究用描述性定性。以测试和访问来收集资料。分析资料显示混淆是结构 助词使用偏误的第一位。尤其在该用结构助词“地”的地方混用了结构助词 “得”或该用结构助词“得”的地方混用了结构助词“地”。此外，学生产生偏误 的原因有：结构助词规律的复杂性、学生个体因素、练习少 和母语的负迁 移四点, 而学生对结构助词“的”、“得”、“地” 教学的需求有两点: 教师的讲 解和多加练习。

关键词: 偏误分析, 结构助词, “的, 得 和 地” 


\section{PENDAHULUAN}

Seiring berkembangnya perekonomian negara Tiongkok, pengaruh bahasa Tionghoa dalam dunia internasioal memiliki peranan yang penting. Berkaitan dengan hal tersebut, perkembangan pembelajaran Bahasa Tionghoa pada pembelajar asing pun juga sangat pesat. Dalam pembelajaran Bahasa Tionghoa, kata abstrak lebih mendapat perhatian daripada kata konkrit. Hal ini ditunjukkan karena jumlah kata abstrak yang tidak banyak ( $\pm 700 \mathrm{kata})$, namun jenis kata ini sering digunakan dalam kehidupan sehari-sehari dan penggunaannya cukup sulit. (Zhang Yi Sheng, Zhang Yi, 2000).

Kata bantu struktural merupakan salah satu bagian dari kata abstrak. Kata bantu struktural khususnya de(的), de(得), de(地) memiliki keunikan tersendiri yaitu memiliki persamaan bunyi (homofon) namun penulisannya dan penggunaannya sangatlah berbeda sehingga hal ini menyebabkan pembelajar seringkali melakukan kesalahan dalam menggunakan kata bantu struktural tersebut. Selain itu, kata bantu struktural tidak dapat berdiri sendiri, sehingga harus digunakan bersamaan dengan kata konkrit, frasa atau kalimat.Dalam tata Bahasa mandarin, kata bantu struktural memiliki peranan yang penting, karena seringkali digunakan. Meskipun dalam mendengar dan berbicara, ketiga kata bantu struktural “的”, “得” dan “地” ini tidak memiliki perbedaan, namun dalam segi membaca dan menulis, ketiga kata bantu struktural “的”, “得”dan “地” sangatlah berbeda dari segi kegunaan maupun cara penggunaannya.

Ada beberapa peneliti yang telah melakukan penelitian mengenai kata bantu struktural, namun sebagian besar hanya meneliti mengenai tata bahasa, penggunaan atau perbedaan dari masing-masing dari ketiga kata bantu struktural “的”, “得” dan “地” tersebut. Maka dari itu, peneliti ingin meneliti lebih dalam lagi dan menggunakan penelitian terdahulu sebagai landasan peneliti dalam menulis penelitian ini. Peneliti menggunakan mahasiswa Universitas Kristen Petra angkatan 2017 prodi Sastra Tionghoa sebagai obyek penelitian. Hal ini dikarenakan materi kata bantu struktural diajarkan pada mahasiswa angkatan 2017, sehingga mahasiswa pun masih fresh dengan pengetahuan baru ini.

Maka peneliti merumuskan permasalahan sebagai berikut:

1. Kesalahan apa saja yang dilakukan mahasiswa Universitas Kristen Petra angkatan 2017 prodi Sastra Tionghoa dalam menggunakan kata bantu struktural de(的), de(得), de(地)?

2. Apa saja faktor penyebab kesalahan mahasiswa Universitas Kristen Petra angkatan 2017 prodi Sastra Tionghoa dalam menggunakan kata bantu struktural de(的), de(得), de(地)?

3. Bagaimana pandangan mahasiswa Universitas Kristen Petra angkatan 2017 prodi Sastra Tionghoa terhadap pengajaran kata bantu struktural de(的), de(得), de(地)? 


\section{KAJIAN PUSTAKA}

\section{Analisis Kesalahan (Error Analysis)}

Error merupakan cerminan seseorang yang sedang berproses dalam belajar. Error terjadi pada pembelajar yang telah mempelajari hal baru, namun melakukan kesalahan dan pembelajar tidak mengetahui letak kesalahannya dimana.

S. Pit Corder adalah orang pertama yang mencetuskan teori mengenai error analysis. Dalam bukunya The Signification of Learner Errors, Ia mengatakan bahwa analisis kesalahan adalah bentuk bahasa yang tidak sesuai dengan gramatikal, juga merupakan tanda kurang sempurnanya pengetahuan dan penguasaan pembelajar. Selain itu, pada tahun 2003 Luo Xiao Jie dan Sun Lin mengembangkan teori ini, ia menjelaskan bahwa error analysis merupakan sebuah analisis yang dilakukan pada pembelajar bahasa kedua yang melakukan kesalahan berbahasa, dengan demikian harus diteliti penyebab kesalahannya sehingga pembelajar tidak melakukan kesalahan lagi

\section{Kata Bantu Struktural de(的), de(得), de(地) dalam Bahasa Mandarin}

Kata bantu struktural adalah kata yang menyatakan struktur atau komposisi dalam kalimat. Li Xiao Qi (2005) mengemukakan bahwa kata bantu struktural dalam bahasa mandarin dibagi menjadi:

1. Kata bantu struktural de(的) adalah kata bantu yang diletakkan di belakang atribut. Ciri-ciri kata bantu struktural “de( 的 )" yaitu (a) menyatakan kepunyaan; (b) menggantikan orang atau benda; (c) digunakan pada akhir kalimat untuk menyatakan penegasan nada. Contoh: 他的书很好看 (Bukunya sangat bagus).

2. Kata bantu struktural de(得) adalah kata yang diletakkan di belakang komplemen atau “de(得)” sebagai lambang komplemen. Contoh: 走得慢 (jalannya lambat).

3. Kata bantu struktural de (地) adalah kata bantu yang khusus diletakkan di belakang adverbial. Contoh: 努力地学习 (Belajar dengan giat).

\section{Penggunaan Kata Bantu Struktural “的”}

Kata bantu struktural “的”merupakan simbol dari atribut, digunakan untuk menghubungkan atribut dan pusat kata, sehingga struktur kalimatnya adalah atribut+ “的”+ pusat kata. Posisi atribut di depan kata “的”dapat berupa kata benda, kata ganti, kata sifat, kata kerja, kata bantu bilangan, frasa, dll. Sedangkan pusat kata yang terletak di belakang kata “的”berupa kata benda atau frasa nomina. Namun di antara atribut dan pusat kata, tidak semua harus ditambah “的”. Adapun yang tidak perlu di tambah kata “的”. (Zhou Mei Ying, 2011, hal. 27).

Menurut Zhou ada beberapa ketentuan penggunaan kata bantu struktural “的” yang perlu diperhatikan: 
1. Kata sifat bersuku kata tunggal yang berperan sebagai atribut, tanpa memperhatikan pusat kata bersuku kata tunggal atau jamak, biasanya tidak ditambah “的”. Contohnya: 红花 ( bunga merah)/ 新衣服 (baju baru)

Namun apabila kata sifat bersuku kata tunggal yang berperan sebagai atribut mengandung makna dan menekankan makna tersebut, maka perlu ditambah “的”.Contohnya: 旧的课本 (buku pelajaran yang lama), 小的衣服是你的 ( pakaian yang kecil itu milik kamu).

2. Kata sifat bersuku kata jamak yang berperan sebagai atribut perlu ditambah “的”, khususnya yang menekankan suatu keadaan.

Contoh: 蓝的天空 (langit yang biru).

Apabila di depan kata sifat terdapat kata yang menyatakan derajat, maka juga perlu ditambah “的”.

Contoh: 很大的广场 (Pusat perbelanjaan yang sangat besar)

3. Kata benda bersuku kata tunggal yang berperan sebagai atribut biasanya ditambah “的”.

Contoh: 水的温度 (temperature air), 花的颜色(warna bunga)

Ketika kata benda bersuku kata jamak berperan sebagai atribut dan pusat katanya bersuku kata tunggal, biasanya ditambah “的”.

Contoh: 中国的茶 (Teh Tiongkok), 河里的鱼 (Ikan di sungai)

4. Kata kerja yang bersuku kata tunggal dan jamak, biasanya perlu ditambah “的”. Contohnya: 炒的菜 (Masakan yang di goreng), 飞舞的雪花 (Kepingan salju yang menari di udara)

5. Kata ganti orang yang berperan sebagai atribut yang menyatakan kepemilikan perlu ditambah “的”.

Contoh: 我的朋友 (teman saya), 他的书 (buku miliknya)

Namun apabila pusat kata adalah Negara, keluarga dekat, lingkungan, dsb tidak perlu ditambah “的”.

Contoh: 我们国家 (negara saya), 他们学校 (sekolah saya), 我爸 (ayah saya).

6. Frasa yang berperan sebagai atribut biasanya menggunakan “的”.

Contoh: 有梦想的人生 (Orang yang memiliki impian)

Selain itu, Huang Bo Rong (2007) dalam bukunya yang berjudul Xiandai

Hanyu menjelaskan beberapa ketentuan lainnya mengenai cara penggunakan kata bantu struktural “的” (hal. 114):

1. Dalam kalimat yang mengandung banyak atribut, maka kata “的” diletakkan setelah atribut yang terakhir.

Contohnya: 这是一个非常错误和愚蚌的决定。

(Ini adalah sebuah keputusan yang salah dan bodoh.)

我的邻居是一位满头白发和蔼可亲的老奶奶。

(Tetangga saya adalah seorang nenek tua yang berambut putih dan ramah)

2. Pada kalimat yang mengandung hubungan kepemilikkan, di antara kata benda dan kata ganti orang dapat di tambah “的” atau tidak ditambah “的”.

Contohnya: 他的老父亲最近身体不太好 / 他老父亲最近身体不太好。

(Beberapa hari ini suaminya kurang sehat) 
3. Untuk membentuk frasa atribut, maka diperlukan kata bantu struktural “的” untuk mengkonstruksi frasa atribut tersebut, sehingga strukturnya menjadi : atribut + “的” + kata benda/ kata ganti orang. Contohnya: 吃的/喝的/红色。 Frasa yang mengandung “的” memiliki lingkup yang luas. Contohnya pada kata “吃的”, kata “的” memberikan keterangan pada kata kerja yaitu “吃” sehingga terdapat beberapa makna. Makna pertama adalah sesuatu yang dikenakan pada kata kerja (sesuatu yang dapat dimakan), makna yang kedua adalah orang yang melakukan kata kerja (orang yang makan) atau bermakna jenis makanannya. Ketika frasa yang mengandung “的” ini diaplikasikan pada sebuah kalimat, maka maknanya semakin jelas dan konkrit. Contohnya: 好饿 啊！给我拿点吃的 ( lapar! beri aku sedikit makanan), maka dalam kalimat ini “吃的” berarti sesuatu yang dapat dimakan.

\section{Penggunaan Kata Bantu Struktural de “得”}

Menurut Liu Yue Hua (2004) penggunaan kata bantu struktural de(得)adalah sebagai berikut (hal. 184):

1. Kata bantu struktural de(得) adalah lambang dari komplemen, dapat digunakan di tengah kata kerja dan kata sifat. Contohnya: 他跑得快。(Larinya cepat)

Kata de(得) dapat diikuti dengan kata keterangan yang menyatakan derajat seperti 很, 非常, dsb. Contohnya: 为了备课, 李老师每天睡得很晚。 (Karena mempersiapkan materi pelajaran, setiap hari Guru Li tidur larut malam). Penggunaan kata de(得) juga dapat digunakan dalam kalimat tanya, contohnya: 她唱得好吗? ( Apakah dia bernyanyi dengan baik?)

2. Kata sifat + de(得) + kata kerja (kata kerja tidak boleh berdiri sendiri) Contohnya: 高兴得大声笑着 (dengan senangnya ia tertawa terbahak-bahak)

3. Kata sifat $+\operatorname{de}($ 得) + kalimat pendek. Contohnya: 累得气都喘不过来(terlalu lelah sampai-sampai nafasnya berat)

4. Kata sifat $+\operatorname{de}($ 得 $)+$ idiom.

Contohnya:搞得乱七八糟 (mengerjakan dengan berantakan)

5. Dalam kalimat negatif, kata "jangan" atau "tidak" diletakkan sebelum kata kerja.

Contohnya:别说得太过分 (jangan berbicara keterlaluan).

6. Pada komplemen hasil, komplemen arah, komplemen jumlah, komplemen derajat, dan komplemen komplemen waktu tidak perlu ditambah “得”. Contoh: 作业写完了(Tugas sudah selesai dikerjakan)/拿出课本(mengambil buku)/住在扬州(tinggal di Yangzhou).

7. Komplemen kondisi yang menyatakan penilaian/melukiskan suatu kejadian, perlu ditambah “得”.

Contoh: 这本书写得好(buku ini ditulis dengan baik) / 那个女孩长得很漂 亮(Anak perempuan itu sangat cantik)/ 妈妈气得说不出话来(Ibu marah hingga tidak dapat berkata-kata). 
8. Komplemen yang menyatakan derajat harus di tambah “得”,namun komplemen derajat seperti“一些、一点”atau“极、透、死、坏”tidak perlu ditambah “得”.

Contoh: 我累死了(saya sangat lelah)/好极了(sangat baik)/淋透了(basah kuyup). Namun ada beberapa komplemen derajat yang perlu memakai “得”. Contohnya: 他高兴得不得了(dia sangat gembira) / 这个地方脏得很(tempat ini sangat kotor)。

\section{Penggunaan Kata Bantu Struktural de “地”}

Kata bantu struktural “地” digunakan untuk menghubungkan kata adverbial dengan pusat kata. Komponen utama di depan kata “地” berupa kata sifat, adverb, kata benda, kata ganti, modal verbs, frasa, dll. Dalam hal ini, pusat kata berperan sebagai kata kerja dan kata sifat. Maka, stuktur kalimatnya menjadi: adverb+ “地”+ pusat kata. Contoh: 非常地热(sangat panas), 快乐地学习(belajar dengan gembira), 仔细地检查 (memeriksa dengan teliti), 聚精会神地听讲(mendengarkan dan menjelaskan dengan konsentrasi) (Suparto, 2003). Namun di dalam penggunaanya, ada beberapa ketentuan yang harus diperhatikan (Liu Yue Hua, 2004, hal. 178) :

1. Adverbial yang bersuku kata tunggal tidak ditambah kata “地” Contohnya: 很好(Sangat baik)/都来(Semua datang)/勿打扰(jangan ramai).

2. Adverbial yang bersuku kata ganda seperti “曾经”、“究竟”、”难道”、“也 许”、”经常”, dll tidak perlu ditambah kata “地”, namun apabila dalam sebuah kalimat lebih menkankan keterangan waktu, maka harus ditambahkan kata “地”.

Contohnya: 他们经常在一起学习。(Mereka sering kali belajar bersama)

3. Kata sifat yang bersuku kata tunggal tidak ditambah “地”, contohnya: 慢跑 (berlari dengan lamban)/大喊(berteriak dengan kencang)/快走(berjalan dengan cepat). Sedangkan Kata sifat bersuku kata ganda yang menyatakan derajat dapat ditambah“地”.

Contohnya : 我们都很积极地参加马拉松比赛。 (Kami semua sangat bersemangat mengikuti lomba marathon)

4. Kata sifat bersuku kata ganda yang berperan dalam kalimat adverbial, dapat menggunakan atau tidak menggunakan kata “地”, bergantung pada keadaan kalimat tersebut. Dalam buku 《实用现代汉语语法》, dikatakan bahwa sebagian besar adjektiv/ frasa adjektiva, kata kerja/ frasa verba, frasa subjekpredikat, frasa nominal, bebas menggunakan atau tidak menggunakan kata “地”, sebagian besar kalimat tidak menggunakan “地”, namun apabila menekankan waktu dapat menggunakan “地”.

Contoh :

a. 你一定要认真回答这些问题。(Kamu harus rajin menjawab soal-soal ini) 
b. 你一定要认真地回答这些问题。(Kamu harus rajin menjawab soal-soal ini)

5. Frasa yang berperan sebagai kalimat adverbial perlu ditambah “地”. Contoh: 虽然天气很热, 但同学们都在聚精会神地听讲。(Meskipun cuaca sangat panas, namun murid-murid sangat bersemangat mendengarkan pelajaran)

6. Kata ganti, kata yang menyatakan waktu dan tempat, modal verbs, preposisi yang berperan sebagai kalimat adverbial tidak ditambah “地”. Contoh:

a. 明天下雨, 记得带伞。(Besok akan hujan, ingatlah untuk membawa payung)

b. 我从头到尾检查了一遍还是没有发现什么问题。(Saya sudah diperiksa dari kepala sampai kaki, namun masih tidak ditemukan kesalahan)

Selain kata yang menyatakan keterangan waktu dan tempat, kata lain yang berperan sebagai kalimat adverbial harus ditambah “地”.

Contoh: 这些钱虽然不多, 但部分地减轻了农民地负担。(Meskipun uang ini tidak banyak, namun dapat meringankan beban masyarakat)

\section{METODE PENELITIAN}

Pada penelitian ini, peneliti menggunakan pendekatan deskriptif kualitatif. Pendekatan kualitatif sering disebut sebagai metode penelitian natutalistik yang berarti penelitiannya dilakukan pada kondisi yang alamiah atau disebut sebagai natural setting. Penelitian ini dilakukan untuk mengamati perilaku yang natural pada obyek penelitian. Hasil pengamatan dari penelitian ini merupakan reaksi alamiah obyek yang tidak dimanipulasi (Sugiyono, 2014, p. 15).

Peneliti memilih pendekatan deskriptif kualitatif karena peneliti ingin mendeskripsikan kesalahan-kesalahan, faktor penyebab kesalahan, serta pandangan mahasiswa terhadap pengajaran kata bantu struktural de(的), de(得), de(地). Hasil penelitian akan peneliti uraikan dengan kata-kata, sehingga dapat dengan mudah di pahami oleh pembaca.

\section{ANALISIS}

\section{Klasifikasi Kesalahan}

Dari hasil tes yang dilakukan oleh mahasiswa Universitas Kristen Petra angkatan 2017 prodi Sastra Tionghoa, ditemukan kesalahan sejumlah 163 buah. Kesalahan-kesalahan tersebut terdiri atas: kesalahan penambahan, kesalahan pengurangan, kesalahan peletakkan dan kerancuan penggunaan kata bantu struktural de(的), de(得), de(地). Berikut adalah hasil analisis kesalahan:

Tabel 1. Tabel Hasil Analisis Kesalahan

\begin{tabular}{|l|l|l|l|}
\hline & $\begin{array}{c}\text { Kesalahan } \\
\text { Penambahan }\end{array}$ & $\begin{array}{l}\text { Kesalahan } \\
\text { Penghilangan }\end{array}$ & $\begin{array}{l}\text { Kesalahan } \\
\text { Peletakkan }\end{array}$ \\
\hline
\end{tabular}




\begin{tabular}{|c|c|c|c|}
\hline 的 & 28 & 28 & 6 \\
\hline 得 & 7 & 0 & 0 \\
\hline 地 & 8 & 0 & 0 \\
\hline Jumlah & 43 & 28 & 6 \\
\hline Persentase & $26,38 \%$ & $17,18 \%$ & $3,68 \%$ \\
\hline & $\begin{array}{l}\text { Kerancuan antara } \\
\text { “的” dan “地” }\end{array}$ & $\begin{array}{l}\text { Kerancuan antara } \\
\text { “的” dan “得” }\end{array}$ & $\begin{array}{l}\text { Kerancuan antara } \\
\text { “地” dan “得” }\end{array}$ \\
\hline & 16 & 27 & 43 \\
\hline Jumlah & \multicolumn{3}{|l|}{86} \\
\hline Persentase & \multicolumn{3}{|l|}{$52,76 \%$} \\
\hline
\end{tabular}

Berdasarkan tabel di atas, dapat diketahui kerancuan penggunaan kata bantu struktural de(的), de(得), de(地) memiliki jumlah persentase terbanyak, khususnya pada kerancuan menggunakan kata struktural de(得) dan de(地), dimana mahasiswa seharusnya menggunakan bantu struktural de(得) namun disalahgunakan menjadi de(地), begitu pula sebaliknya. Kesalahan kedua yang sering kali dijumpai adalah kesalahan penambahan dan pengurangan kata bantu struktural de(的), de(得), de(地), khususnya pada penggunaan kata de(的).

\section{Faktor Penyebab Kesalahan}

Faktor penyebab pertama adalah kerumitan penggunaan kata bantu struktural de(的), de(得) dan de(地). Berdasarkan hasil wawancara, dapat diketahui bahwa seluruh mahasiswa menyatakan bahwa penggunaan kata bantu struktural sulit. Kata bantu struktural de(的), de(得) dan de(地) memiliki persamaan bunyi (homofon). Meskipun memiliki pelafalan yang sama, namun dalam penulisan ketiga kata bantu struktural de(的), de(得) dan de(地) ini tidaklah sama, baik dalam kegunaan maupun cara penggunaannya. Hal ini membuat mahasiswa tingkat pemula mengalami kesulitan dalam membedakan ketiga kata bantu tersebut. Kedua adalah faktor dalam diri mahasiswa. Dalam proses belajar motivasi sangat diperlukan, karena motivasi merupakan tenaga yang menggerakkan dan mengarahkan kita untuk belajar sehingga mencapai tujuan. Namun dari hasil wawancara, peneliti mengetahui bahwa mahasiswa tidak memiliki motivasi belajar, hal ini ditunjukkan dari pernyataan seluruh mahasiswa yang menyatakan bahwa hanya belajar ketika sebelum ujian saja. Selain itu mahasiswa juga tidak mengulang kembali materi pembelajaran baru yang diajarkan di dalam kelas. Ketiga, berdasarkan hasil wawancara seluruh mahasiswa menyatakan bahwa penyebab kesalahan penggunaan kata bantu struktural adalah kurangnya latihan soal.Latihan soal terhadap pembelajar bahasa kedua sangatlah penting, semakin sering latihan soal maka pembelajar semakin menguasai pengetahuan baru yang dipelajari. Dari hasil wawancara, peneliti mengetahui bahwa salah satu penyebab mahasiswa melakukan 
kesalahan dalam penggunaan kata bantu struktural tersebut adalah kurangnya latihan soal. Latihan soal dalam buku paket mahasiswa sangatlah sedikit, pengajar juga tidak memberikan latihan lebih kepada mahasiswa. Hal ini menyebabkan mahasiswa kurang memperhatikan materi pembelajaran ini dan menganggapnya kurang penting. Terakhir adalah adanya pengaruh Bahasa ibu. Dapat diketahui terdapat 4 mahasiswa yang menyatakan bahasa ibu memiliki dampak yang kurang baik terhadap pemahaman penggunaan kata bantu struktural. Mereka mengatakan bahwa tata bahasa mandarin dan bahasa Indonesia berbeda, sehingga terkadang bingung untuk mengaplikasikan kata bantu struktural tersebut dalam kalimat.

\section{Pandangan Mahasiswa Terhadap Cara Pengajaran Kata Bantu Struktural de(的), de(得) dan de(地)}

Dari hasil wawancara, peniliti dapat menyimpulkan pandangan mahasiswa terhadap cara pengajaran kata bantu struktural de(的), de(得) dan de(地). Pertama adalah penjelasan pengajar. Cara penjelasan pengajar dalam menyampaikan materi pelajaran baru kepada mahasiswa sangatlah penting. Dalam hasil wawancara, peneliti dapat mengetahui bahwa mahasiswa tidak suka dengan cara penyampaian dosen yang terlalu banyak teori dan menggunakan bahasa teoritis. Mahasiswa lebih cepat paham apabila materi kata bantu struktural disampaikan dengan bahasa sehari-hari yang mudah dipahami. Kedua adalah memperbanyak latihan soal. Latihan soal memiliki pengaruh pada daya ingat mahasiswa. Mahasiswa berharap pengajar memperbanyak latihan soal, karena dengan adanya latihan soal mahasiswa tidak mudah melupakan materi yang diajarkan pengajar mengenai kata bantu struktural de(的), de(得) dan de(地) dan hal ini dapat membuat mahasiswa terbiasa menggunakan kata bantu struktural. Dari hasil wawancara juga dapat diketahui bahwa mahasiswa lebih tertarik dengan metode pembelajaran yang modern, yaitu dengan menggunakan laptop atau gadget. Dalam hal ini, pengajar dapat memberikan quiz, test, ataupun tugas dalam sebuah aplikasi, contohnya: Edmodo.

\section{KESIMPULAN}

Berdasarkan hasil tes mahasiswa Universitas Kristen Petra angkatan 2017 prodi Sastra Tionghoa, dapat diketahui bahwa kesalahan pertama yang paling banyak dilakukan oleh mahasiswa adalah kerancuan, khususnya adalah kerancuan dalam menggunaan kata bantu struktural de(得) dan de(地). Kesalahan kedua yang seringkali dijumpai adalah kesalahan penambahan dan kesalahan pengurangan, terutama pada kata bantu stuktural de(的). Terakhir adalah kesalahan peletakkan kata bantu struktural, kesalahan ini paling sedikit dilakukan oleh mahasiswa.

Melalui wawancara, Peneliti menemukan faktor penyebab mahasiswa melakukan kesalahan dalam menggunakan kata bantu struktural de(的), de(得) dan de(地), diantaranya: penggunaan kata bantu struktural yang rumit, faktor dalam diri mahasiswa, kurangnya latihan soal dan adanya pengaruh dari Bahasa ibu. Selain itu melalui hasil wawancara, peneliti juga mengetahui pandangan mahasiswa terhadap cara pengajaran kata bantu struktural de(的), de(得) dan de(地) diantaranya adalah: cara penjelasan pengajar yang sangat berpengaruh terhadap tingkat pemahaman 
mahasiswa serta memperbanyak latihan soal dapat membuat mahasiswa tidak mudah melupakan materi yang diajarkan.

\section{SARAN}

Bagi pengajar, pengajar dapat memberikan contoh kalimat sederhana terlebih dahulu kepada mahasiswa agar mahasiswa dapat dengan mudah memahami kegunaan dan perbedaannya. Apabila mahasiswa sudah paham, pengajar dapat melanjutkan pengajaran pada materi yang lebih sulit yaitu mengenai ketentuanketentuan penggunaan kata bantu struktural, kemudian kembali memberikan contoh pada masing-masing ketentuan penggunaannya.

Bagi peneliti selanjutnya dapat meneliti mengenai kata bantu struktural $\mathrm{de}$ (的), de(得), de(地) dilihat dari sudut pandang yang lain, misalnya mengenai cara pengajaran kata bantu struktural. Dalam hal ini, peneliti selanjutnya dapat menggunakan data dalam penelitian ini untuk mengetahui kondisi mahasiswa dalam menggunakan kata bantu struktural de(的), de(得), de(地). Setelah itu, peneliti selanjutnya juga dapat menggunakan objek penelitian yang lebih beragam, misalnya pada mahasiswa yang angkatannya berbeda atau tingkat kemampuannya berbeda.

\section{DAFTAR PUSTAKA}

Corder, S.P. (1967).The Significance of Learners' Errors. International Review of Applied linguistics, 5.

Huang, B.R \& L,X.D. (2007).Xiandai Hanyu. Beijing: Gaodeng Jiaoyu

Chubanshe.

Li, X.Q.(2005). Xiandai Hanyu Xuci Jiangyi. Beijing: Beijing Daxue Chubanshe. Liu, Y.H. (2004). Shiyong Xiandai Hanyu Yufa. Beijing: Shangwu Yinshuguan

Luo,X.J \& Sun, L. (2003). Pianwu Lilun yu Eryu Xide. Waiyu Xuekan, (2), 102105.

Sugiyono. (2014). Metode Penelitian Pendidikan. Bandung: Alfabeta.

Suparto.(2003). Tata Bahasa Mandarin Itu Mudah. Jakarta: Puspa Swara.

Zhou,M.Y.(2011). Guanyu Liuxuesheng Hanyu jiegouzhuci "de" he "de" de Xide Kaocha. Master thesis, Fujian Normal University.

Zhang,Y.S \& Zhang, B. Xiandai Hanyu Xuci. Huadong: Huadong Daxue Chubanshe. 